\title{
The Impact of Banking Sector Stability on the Real Economy
}

Pierre Monnin and Terhi Jokipii

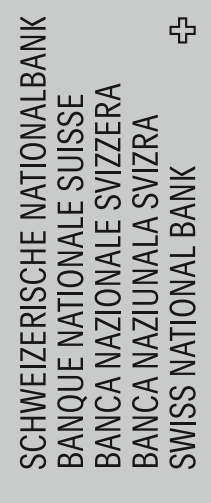


The views expressed in this paper are those of the author(s) and do not necessarily represent those of the Swiss National Bank. Working Papers describe research in progress. Their aim is to elicit comments and to further debate.

\section{Copyright $\odot$}

The Swiss National Bank (SNB) respects all third-party rights, in particular rights relating to works protected by copyright (information or data, wordings and depictions, to the extent that these are of an individual character). SNB publications containing a reference to a copyright ( $\odot$ Swiss National Bank/SNB, Zurich/year, or similar) may, under copyright law, only be used (reproduced, used via the internet, etc.) for non-commercial purposes and provided that the source is mentioned. Their use for commercial purposes is only permitted with the prior express consent of the SNB.

General information and data published without reference to a copyright may be used without mentioning the source.

To the extent that the information and data clearly derive from outside sources, the users of such information and data are obliged to respect any existing copyrights and to obtain the right of use from the relevant outside source themselves.

\section{Limitation of liability}

The SNB accepts no responsibility for any information it provides. Under no circumstances will it accept any liability for losses or damage which may result from the use of such information. This limitation of liability applies, in particular, to the topicality, accuracy, validity and availability of the information.

ISSN 1660-7716 (printed version)

ISSN 1660-7724 (online version)

๑ 2010 by Swiss National Bank, Börsenstrasse 15, P.0. Box, CH-8022 Zurich 


\title{
The Impact of Banking Sector Stability on the Real Economy *
}

\author{
Pierre Monnin ${ }^{\mathrm{a}, *}$, Terhi Jokipii ${ }^{\mathrm{b}}$ \\ ${ }^{a}$ Swiss National Bank, Financial Market Analysis, Boersentrasse 15, 8022 Zurich, \\ Switzerland \\ b Swiss National Bank, Financial Stability, Bundesplatz 1, 3001 Bern, Switzerland
}

\begin{abstract}
This article studies the relationship between the degree of banking sector stability and the subsequent evolution of real output growth and inflation. Adopting a panel VAR methodology for a sample of 18 OECD countries, we find a positive link between banking sector stability and real output growth. This finding is predominantly driven by periods of instability rather than by very stable periods. In addition, we show that an unstable banking sector increases uncertainty about future output growth. No clear link between banking sector stability and inflation seems to exist. We then argue that the link between banking stability and real output growth can be used to improve output growth forecasts. Using Fed forecast errors, we show that banking sector stability (instability) results in a significant underestimation (overestimation) of GDP growth in the subsequent quarters.
\end{abstract}

Key words: Banking sector stability, real output growth, output growth forecasts.

JEL classification: E20, E44, G21.

\footnotetext{
${ }^{\star}$ The authors thank Signe Krogstrup for collecting data on inflation and growth forecasts. We also thank an anonymous referee and the members of the SNB Financial Stability group for their useful comments. The opinions expressed herein are those of the authors and do not necessarily reflect the views of the Swiss National Bank.

* Corresponding author. Tel: +413132706 69. Fax: +413132707 28.

Email addresses: pierre.monnin@snb.ch (Pierre Monnin), terhi.jokipii@snb.ch (Terhi Jokipii).
}

April 2010 


\section{Introduction}

The increased incidence of banking and financial crises over the last quarter century has triggered an active research agenda, not only on the underlying causes of crises, but also on their impact on the real economy. Literature in this field has been mainly focussed in two directions: first, on understanding links between banking sector characteristics and long term growth and, second, on quantifying the costs of banking sector crises in terms of real output losses. In the first strand of research, Levine $(1997,2001)$ demonstrates the link between the openness of the banking sector and economic growth. Several other authors (Levine, 1997, 1998, Levine, Loayza, and Beck, 2000, King and Levine, 1993a,b, Demirgüç-Kunt and Maksimovic, 1998, Rajan and Zingales, 1986) have highlighted that the degree of development in the financial sector acts as an important contributor to economic growth. ${ }^{1}$ The second strand of research reaches a clear conclusion: banking crises have usually coincided with, or preceded, a substantial economic slowdown (see among others Hogart, Reis, and Saporta, 2002, Boyd, Kwak, and Smith, 2005, Serwa, 2007, Kroszner, Laeven, and Klingebiel, 2007, Dell'Ariccia, Detragiache, and Rajan, 2008). The literature is however, far less clear regarding whether or not the banking sector is the main trigger of the economic slowdown, as it is difficult to separate cause and effect in the financial sector real economy nexus (Kaminsky and Reinhart, 1999, Demirgüç-Kunt and Detragiache, 1997, 2005, Hilbers, Otker-Robe, Pazarbasioglu, and Johnsen, 2005). These empirical conclusions have prompted an increased interest in both policy makers and academics to assess, from a theoretical point of view, the extent to which macroeconomic policies and banking system soundness depend on one another (Benink and Benston, 2005, Gupta, 2005, European Central Bank, 2006, Deutsche Bundesbank, 2006, Goodhart, Sunirand, and Tsomocos, 2006).

This paper clearly belongs to the second strand of research. Indeed, we are not concerned by the effect of financial development on long term growth, but rather by the (possibly transitory) impact of banking sector instability on real output growth. We are also not interested in investigating the events at the roots of banking sector instability per se, and thus we take banking sector instability as given, without examining its causes. One flaw of the studies cited above in the second strand of research is that they focus solely on the loss in output growth during or after banking crises, ignoring the banking sectors impact during more stable times. ${ }^{2}$ The main reason for this is that many authors have chosen to work with binary dependent variables (crisis vs. non crisis). However, several drawbacks are associated with adopting this approach. First, bank crises are relatively rare events. Second, the choice of

\footnotetext{
${ }^{1}$ This literature is reviewed in Levine (2004).

${ }^{2}$ One exception to this is Rancière, Tornell, and Westermann (2008) who shows a positive link between average growth and banking sector instability.
} 
threshold for defining a crisis is highly discretionary. Finally, binary variables impose the unrealistic assumption that a banking sector that is not experiencing a crisis is necessarily healthy. The focus on crises vs. non crisis periods has consequently resulted in a lack of research into the impact of the banking sector on the real economy in less extreme times. It remains unclear whether 'normal' reductions in banking sector stability - i.e. a level of instability that can regularly be observed but that does not translate into a banking crisis have a significant impact on growth. ${ }^{3}$

In this paper, we contribute to the literature by empirically assessing whether the degree of banking sector stability has an impact on the real economy in non extreme times. In particular, we are interested in determining whether a period of banking sector instability is followed by reduced real output growth in the subsequent quarters. We measure banking sector stability based on the banking sector's probability of default. This measure has the advantage of being continuous by nature and thus captures a continuum of states, rather than classification as either crisis or non crisis. This contrasts with the binary variables approach usually adopted in this context. In contrast to other distance-to-default measures previously used, our measure allows for a timevarying volatility for banks assets. Following Aspachs, Goodhart, Tsomocos, and Zicchino (2007), we explore the impact of banking sector stability on real output growth and inflation rates in the subsequent quarters with a panel vector autoregressive model ${ }^{4}$. Our sample consists of quarterly data for 18 OECD countries over the 1980-2008 period. The novelty of our set-up is that it allows the variance of output growth to be dependant of the state of the banking sector. This captures the impact of banking sector instability on output growth as well as on its uncertainty.

Our results can be summarized as follows: banking sector stability is an important driver of future GDP growth. Periods of stability are generally followed by an increase in real output growth and vice versa, a finding which appears to be driven predominantly by periods of relative instability rather than by periods of stability. In addition, we show that banking sector instability is followed by higher uncertainty about output growth.

The link between banking sector stability and economic activity is of particular interest to policy makers which base their monetary policy decisions on economic forecasts. Research focussing on understanding whether financial stability should be considered in the setting of monetary policy has investigated the

\footnotetext{
${ }^{3}$ For example, consider a banking sector which suffers credit losses in a business cycle downturn but which is still able to function without external help. The stability of such a banking sector has clearly decreased after credit losses, but since it is still functioning, it is not in a fully fledged crisis either.

${ }^{4}$ Allenspach and Perrez (2008) study interactions between the banking sector and the real economy for Switzerland via a VAR approach, however it is a single country study that does not make use of the panel VAR methodology adopted here.
} 
informational advantages of the central bank, and in particular whether bank related information can be used to improve macro forecasts. Peek, Rosengren, and Tootell (1999, 2003), Romer and Romer (2000) show that incorporating confidential supervisory information about bank health improves central bank forecasts of both unemployment and inflation, and that in fact, the Federal Open Market Committee (FOMC) consider this information when setting monetary policy. We contribute to this literature by extending our analysis further and investigating the results uncovered thus far. In particular, our results indicated an apparent importance of banking sector stability on output growth. We continue by assessing whether additional information embedded in our stability index might help to improve output growth forecasts. Using Feds forecasts data, we show that banking sector stability (instability) results in a significant underestimation (overestimation) of GDP growth in the subsequent quarters. This finding indicates that additional information embedded in our stability measure has the potential to further improve economic forecasts.

The rest of this paper is organized as follows. Section 2 defines our measure of banking sector stability. Section 3 describes the data used. Section 4 estimates the impact of banking sector stability on output and inflation. Section 5 explores the relationship between banking sector stability and central bank forecast errors. Section 6 concludes.

\section{Stability index for the banking sector}

\subsection{Banking sector stability: definition and assumptions}

We define the instability as the probability of the banking sector becoming insolvent within the next quarter. Hence, a lower probability corresponds to greater stability and vice verse. We consider a banking sector to be insolvent if, at the end of the quarter, the market value of the assets owned by all the banks of a country is not sufficient to repay its total debt (i.e. if at time $t+1$, the total assets $A_{t+1}$ of the banks are smaller than their total debt $D_{t+1}$ ). This approach makes the implicit assumption that the banking sector of country $i$ is equal to a single bank, computed as the the aggregate of the balance sheets of banking institutions in that country. Our measure therefore abstracts from any comptetiveness considerations.

To compute the default probability of the banking sector $i$ at time $t$, two elements are required: the distributions of both the asset value and of the debt value at the end of the period, conditional on their initial values at time $t$. With these two distribution functions, we are able to compute the probability that, at time $t+1$, the asset value falls below the debt value. 
We assume that the asset value of the banking sector follows a geometric Brownian motion characterized by:

$$
d A_{t}=\mu A_{t} d t+\sigma_{t} A_{t} d w
$$

where $\mu$ is the instantaneous growth rate of assets, $\sigma_{t}$ is their instantaneous volatility rate and $d w$ is a Wiener process. We also assume that, between $t$ and $t+1$, debt grows at the (continuously compounded) growth rate $r$, which implies the following one-period transition function:

$$
D_{t+1}=D_{t} e^{r}
$$

\subsection{Default probability and distance-to-default for the banking sector}

To estimate the default probability of a firm (i.e. of the aggregate banking sector in our case), Merton (1974) suggests considering the firm's equity as a call option on its assets. Merton's method is based on the idea that if, at debt maturity, the value of the firm's assets is smaller than its debt, then the firm cannot repay its debt and becomes insolvent. In this case, the firm's equity is worth zero. If the assets are greater than the debt, then the firm repays its debt and the market value of the firm is equal to the difference between the asset value and the debt. Thus Merton's model states that, at debt maturity (i.e. $t+1$ in our case), the firm's equity is equal to:

$$
\max \left(A_{t+1}-D_{t+1}, 0\right)
$$

By assuming, as stated in section 2.1 that $A_{t}$ is $\log$ normally distributed and that debt is insured, ${ }^{5}$ Merton (1974) shows, using the Black-Scholes option pricing formula, that the initial price $E_{t}$ of the banking sector's equity is:

$$
E_{t}=A_{t} \Phi\left(d_{t}+\sigma_{t}\right)-D_{t} \Phi\left(d_{t}\right)
$$

with

$$
d_{t}=\frac{\ln \left(A_{t} / D_{t}\right)-\sigma_{t}^{2} / 2}{\sigma_{t}}
$$

where $\Phi(\cdot)$ is the cumulative normal distribution.

Note that $\Phi\left(d_{t}\right)$ in equation (4) corresponds to the probability of exercising the option (i.e. the probability that the assets $A_{t+1}$ are greater than the debt $D_{t+1}$ ). Therefore, the probability of default (i.e. the probability of not exercising the option) is equal to $1-\Phi\left(d_{t}\right)$. One can show (see Bichsel and Blum, 2004) that $d_{t}$ measures how far, in terms of standard deviations, the banking sector is

\footnotetext{
${ }^{5}$ This assumption implies that bank's bonds will yield the risk free rate even in case of default for the bank.
} 
from its default point (i.e. the point where assets are equal to debt). This is why $d_{t}$ is often called the distance-to-default.

Concretely, for the rest of our analysis, we will not work with the default probability directly but we will rather use the distance-to-default $d_{t}$. Note that these two measures are equivalent since they are linked by a strictly continuously decreasing function. A lower distance-to-default always implies a higher probability of default. The distance-to-default measure has the advantage of being unbounded, which is convenient for empirical estimations. The default probability on the other hand, is bounded between zero and one.

To compute the distance-to-default with equation (5), we need to know the asset market value $A_{t}$, its volatility rate $\sigma_{t}$ and the debt $D_{t}$. In practice however, only debt is directly observable. To obtain the asset market value, and its variance rate we make use of equation (4) which links the unobserved assets with the observed market capitalization of the banking sector (i.e. its equity value $E_{t}$ ).

\subsection{Estimation of the distance-to-defaults with equity market value}

Duan $(1994,2000)$ shows how to estimate the unobserved evolution of the asset value and its variance making use of the observed evolution of market capitalization. In his original paper, Duan (1994, 2000) works with a constant variance; we extend his method to estimate a time-varying variance.

We start by rewriting equation (1) to get the one-period transition density of $A_{t}$, which is equal to:

$$
\Delta \ln A_{t+1}=\mu-\sigma_{t}^{2} / 2+\omega_{t}
$$

where $\Delta \ln A_{t+1}=\ln A_{t+1}-\ln A_{t}$ and $\omega_{t}$ is white noise with variance $\sigma_{t}^{2}$. Furthermore, we assume that the variance follows a $\operatorname{GARCH}(1,1)$ process characterized by:

$$
\sigma_{t}^{2}=\kappa+\alpha \epsilon_{t-1}^{2}+\beta \sigma_{t-1}^{2}
$$

The unknown parameters are $\theta=\{\mu, \kappa, \alpha, \beta\}$. Duan $(1994,2000)$ makes use of the fact that for any given set of parameters $\theta$, equation (4) is a one-to-one mapping between $E_{t}$ and $A_{t}$. The parameter set $\theta$ can therefore be estimated by maximizing a log likelihood function defined on $E_{t}$ instead of on $A_{t}$. Duan (1994, 2000) shows that the log likelihood function takes the form: 


$$
\begin{aligned}
L\left(E_{t}, \theta\right)= & -\sum_{t=1}^{T-1} \ln \Phi\left(\hat{d}_{t}+\sigma_{t}\right)-\frac{T-1}{2} \ln (2 \pi)-\frac{1}{2} \sum_{t=1}^{T-1} \ln \sigma_{t}^{2} \\
& -\sum_{t=1}^{T-1} \ln \hat{A}_{t+1}-\frac{1}{2} \sum_{t=1}^{T-1} \frac{\left(\Delta \ln \hat{A}_{t+1}-\left(\mu-\sigma_{t}^{2} / 2\right)\right)^{2}}{\sigma_{t}^{2}}
\end{aligned}
$$

where $\hat{A}_{t}$ is the unique solution to equation (4) for $E_{t}$, given that the parameters $\theta$ and $\hat{d}_{t}$ correspond to $d_{t}$ with $\hat{A}_{t}$ instead of $A_{t}$. Note that the three last terms on the right-hand side of the previous equation would correspond to the log likelihood functions of a GARCH process if the asset value were directly observable. The first term on the right-hand side of the equation corrects this traditional log likelihood function to account for the fact that we must obtain the asset value $A_{t}$ from the observable equity price $E_{t}$ via equation (4). The maximization of the log likelihood function can be performed with ordinary maximization techniques.

\section{Data}

Our dataset consists of debt and market value data between 1980Q1 and 2008Q4 for a sample of 521 banks covering 18 OECD countries. ${ }^{6}$ All data are obtained from Datastream. The debt data are annual and have been transformed into quarterly data by linear interpolation. The quarterly market value is the minimum of daily market values observed during the quarter. ${ }^{7}$

In addition to the data used to calculate the distance-to-default index for each country, we make use of GDP real growth and inflation between 1980Q1 and 2008Q4. The seasonality component in price movement is removed using the $\mathrm{X} 12$ method in Eviews.

Figure 1 presents the estimated distance-to-defaults for each country. We assume that in each country, banking sector stability is measured by the relative size of distance-to-default deviations from its own historical mean. In other words, an unusually unstable banking sector corresponds to a distance-todefault that is substantially below the country historical mean. The horizontal lines represent the first and third quartiles of the distance-to-defaults of all

\footnotetext{
${ }^{6}$ We selected countries that joined the OECD before 1975 and that are classified as highincome countries by the World Bank. These countries are Australia (17 banks), Austria (10 banks), Belgium (12 banks), Canada (10 banks), Denmark ( 52 banks), France (47 banks), Germany (32 banks), Greece (21 banks), Italy (50 banks), Ireland (5 banks), Japan (110 banks), Norway (32 banks), Portugal (9 banks), Spain (23 banks), Sweden ( 7 banks), Switzerland (33 banks), United Kingdom (14 banks) and United States (37 banks). Finland, Iceland, Luxembourg, Netherlands and New Zealand have been excluded because we could not get data for at least 5 banks.

${ }^{7}$ We additionally experiment by using the average market value observed during the quarter. However the results are not significantly affected and are therefore not presented here for brevity.
} 
countries. These quartiles are used in Section 4.2 to define the thresholds of stability on which we base our assessment. We define three possible states for the banking sector: unstable, stable and very stable. We consider a banking sector to be unstable if its distance-to-default is in the first 20

Figure 2 shows the number of countries with an unstable banking sector in each period. We can observe four periods in which at more than third of the countries simultaneously experience instability in their banking sector: 1987Q4 (Black Monday and the following stock market crisis), 1990Q1 - 1993Q2 (housing crises in several countries), 1998Q3 (Russian and LTCM crises) and in 2008 (subprime crisis).

\section{Impact of banking sector stability real output growth and infla- tion}

In order to assess whether banking sector stability is linked to real output growth and inflation we adopt a panel autoregression (pVAR) approach with state-dependent variance. We make use of a pVAR approach predominantly for the reason that the interactions between financial distress and the real economy have not been rigorously identified theoretically. Using a VAR therefore allows us to impose as little a priori theorizing as possible. Moreover, a panel VAR, when compared to a traditional VAR approach, allows us, by using cross sectional data, to increase the number of observations and thus the precision of our estimations. This is particularly useful in our context since episodes of banking sector instability are relatively rare. The choice of a state-dependent variance derives from a preliminary analysis showing that the residuals of a simple pVAR were heteroscedastic. Thus, in addition to studying the impact of banking sector stability on the levels of GDP growth and inflation, our framework allows us to explore its impact on both GDP growth and inflation uncertainty.

The pVAR model has the following specification:

$$
y_{i t}=A y_{i t-1}+B x_{i t}+\mu_{i}+H_{i t}^{1 / 2} \varepsilon_{i t}
$$

where $y_{i t}$ is a vector of endogenous variables for country $i$ at time $t$ (i.e. output growth, inflation and banking sector stability), $x_{i t}$ is a vector of exogenous variables (i.e. oil prices), $\mu_{i}$ is a fixed effect for each country, $\varepsilon_{i t}$ is a vector of independent error terms normally distributed and $H_{i t}$ is a country-specific time-varying covariance matrix, which is function of a set of dependent variables $z_{t-1}$ (see below).

To model $H_{i t}$, we adopt a strategy similar to the conditional constant correlation (CCC) of Bollerslev (1990). The covariance matrix can be decomposed 

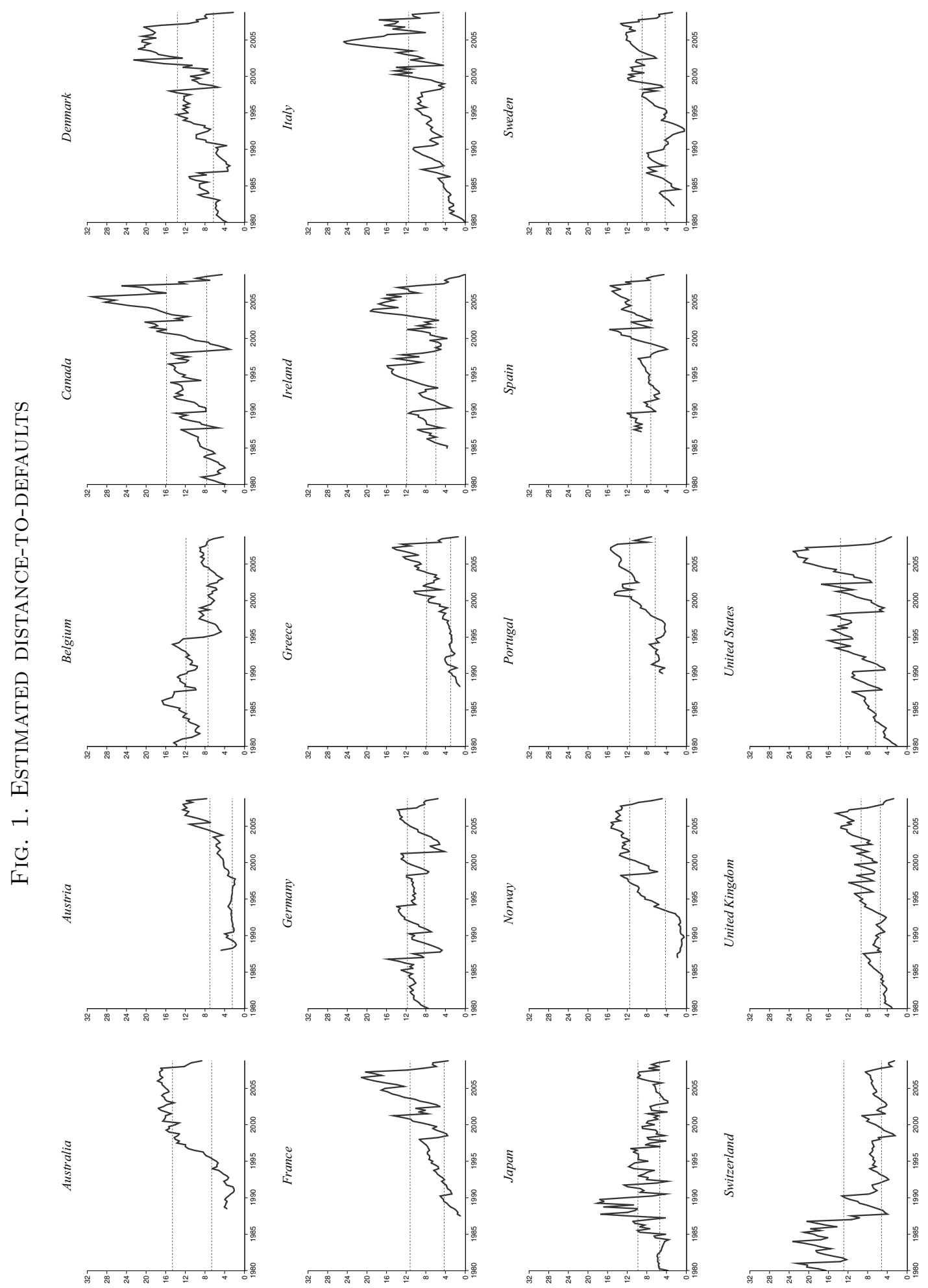


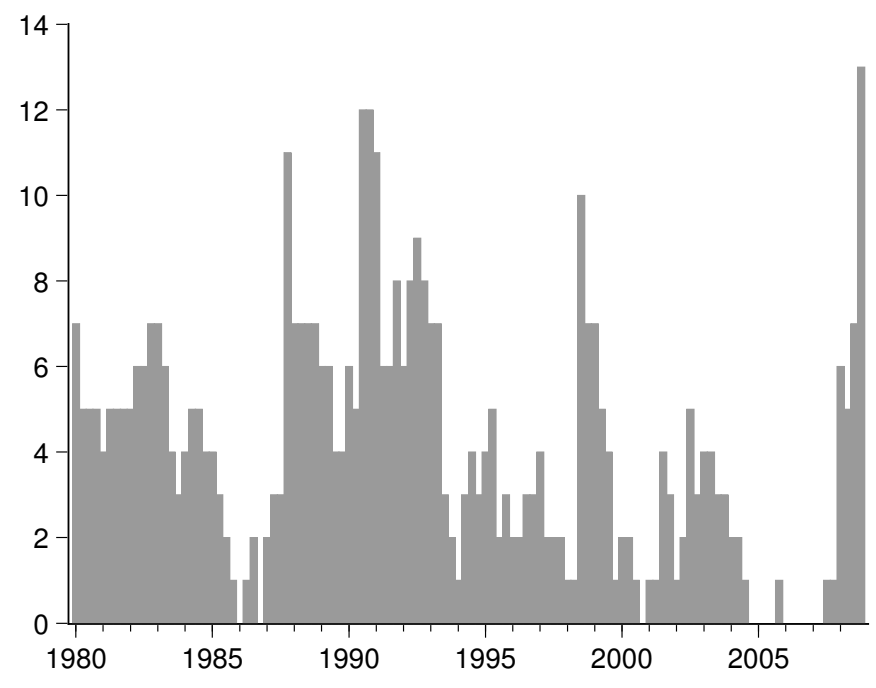

as:

$$
H_{i t}=D_{i t} R_{i} D_{i t}
$$

with

$$
R_{i}=\left(\begin{array}{ccccc}
1 & \phi_{i 12} & \phi_{i 13} & \cdots & \phi_{i 1 N} \\
\phi_{i 21} & 1 & \phi_{i 23} & \cdots & \phi_{i 2 N} \\
\vdots & \vdots & \vdots & \ddots & \vdots \\
\phi_{i N 1} & \phi_{i N 2} & \phi_{i N 3} & \cdots & 1
\end{array}\right)
$$

where $\phi_{i j k}$ is a constant country-specific correlation coefficient between variables $j$ and $k$ in $y_{i t}$ and

$$
D_{i t}^{2}=\left(\begin{array}{ccccc}
\sigma_{i t 1}^{2} & 0 & 0 & \cdots & 0 \\
0 & \sigma_{i t 2}^{2} & 0 & \cdots & 0 \\
\vdots & \vdots & \vdots & \ddots & \vdots \\
0 & 0 & 0 & \cdots & \sigma_{i t N}^{2}
\end{array}\right)
$$

where $\sigma_{i t n}^{2}$ is the variance of residuals for country $i$ at time $t$ for the $n$th variables of $y_{i t}$. Each variance depends of a set of past variables $z_{i t}$ through the following function:

$$
\sigma_{i t n}^{2}=\exp \left(\alpha_{i n}+\alpha_{n} z_{i t-1}\right)
$$

where $\alpha_{i n}$ is a fixed effect specific to each country and $\alpha_{n}$ is a common slope. Note that $z_{i t}$ can contain some or all variables in $y_{i t}$ and $x_{i t}$. 
The likelihood function of the pVAR given $\theta$ is:

$$
L=\prod_{t=1}^{T} \prod_{i=1}^{I} \frac{1}{(2 \pi)^{N / 2}\left|H_{i t}\right|^{1 / 2}} \exp \left(-\frac{1}{2} \varepsilon_{i t}^{\prime} H_{i t}^{-1} \varepsilon_{i t}\right)
$$

where $T$ is the number of periods, $I$ is the number of countries and $N$ is the number of variables in each vector $y_{i t}$. The log likelihood function is then:

$$
l=\sum_{t=1}^{T} \sum_{i=1}^{I}-\frac{N}{2} \ln (2 \pi)-\frac{1}{2} \ln \left|H_{i t}\right|-\frac{1}{2} \varepsilon_{i t}^{\prime} H_{i t}^{-1} \varepsilon_{i t}
$$

The log likelihood can be estimated with traditional maximization techniques. We use a multivariate version of the estimation methodology proposed by Harvey (1976).

The model is estimated using GDP real growth, price level and oil price growth rate data between 1980Q1 and 2008Q4 collected from Datastream. ${ }^{8}$ Note that we standardize ${ }^{9}$ the distance-to-default for each country. With this, we eliminate the difference in distance-to-default level and volatility between countries. This is equivalent to assuming that, in each country, banking sector stability is measured by the relative size of distance-to-default deviations from each country historical mean. In other words, an unusually unstable banking sector corresponds to a distance-to-default that is unusually below the country historical mean, in terms of historical standard deviations.

\subsection{Linear impact of banking sector stability}

\subsubsection{Impact on real output growth}

Table 1 displays the estimated coefficients of the pVAR model with a lag of two for the endogenous and the exogenous variables. ${ }^{10}$ For clarity, only coefficients related to the endogenous and exogenous variables are presented; fixed effects are omitted. The estimated coefficients show that the relationship between banking sector stability and real output growth is a two way relationship. Real output growth is important for subsequent stability and similarly, banking sector stability is important for subsequent output growth. In particular, our results indicate that higher growth is followed by greater banking sector stability (column 2, row 1) and that banking sector stability induces growth in the subsequent periods (column 1, rows 3 and 4 ).

\footnotetext{
${ }^{8}$ We removed the seasonality component in price movement using the X12 method in Eviews.

${ }^{9} \mathrm{~A}$ standardized variable is equal to its value subtracted from its mean and divided by its standard deviation.

10 The number of lags has been chosen with the Akaike Information Criterion.
} 
TABLE 1

LINEAR IMPACT OF BANKING SECTOR STABILITY

ON REAL OUTPUT GROWTH

\begin{tabular}{c|cc|cc}
\hline \hline & \multicolumn{2}{|c|}{ Level } & \multicolumn{2}{c}{ Variance } \\
& $G D P_{t}$ & \multicolumn{1}{|c}{$D D_{t}$} & $\log \left(\sigma_{G D P_{t}}^{2}\right)$ & $\log \left(\sigma_{D D_{t}}^{2}\right)$ \\
\hline$G D P_{t-1}$ & $0.2035^{* *}$ & $2.2104^{* *}$ & $-16.2861^{* *}$ & -3.7156 \\
$G D P_{t-2}$ & $0.1982^{* *}$ & 0.1754 & -6.8144 & $11.0961^{* *}$ \\
$D D_{t-1}$ & $0.0011^{* *}$ & $0.9671^{* *}$ & $-0.3239^{* *}$ & $0.6499^{* *}$ \\
$D D_{t-2}$ & $-0.0010^{* *}$ & -0.0093 & 0.0060 & $0.3483^{* *}$ \\
$O i l_{t}$ & 0.0006 & -0.0495 & & \\
$O i l_{t-1}$ & $-0.0020^{* *}$ & -0.0397 & & \\
$O i l_{t-2}$ & -0.0011 & $-0.0526^{*}$ & & \\
\hline \hline & $*(* *)$ indicates that the coefficient at significant at the 5\% (1\%) level. Level: \\
estimated coefficients of equation (8) with GDP growth and banking sector's \\
distance-to-default as endogenous variables and oil price yield as exogenous \\
variable. Variance: estimated coefficients for equation (12) with GDP growth \\
and banking sector's distance-to-default as independent variables.
\end{tabular}

The positive impact of banking sector stability on output growth is observable from the impulse-response functions of the estimated pVAR (lower left-hand side panel in Figure 3). Moreover, shocks (both to banking sector stability and to output growth) are more persistent in their effect on banking sector stability than on output growth (right-hand side vs. left-hand side panels of Figure 3). The impulse-response functions also show that the impact of a positive GDP shock on the improvement of banking sector stability is long lasting.

Table 1 additionally presents the estimated coefficients for the output growth and banking sector stability variances. The results indicate that both the level of output growth and banking sector stability have a significant impact on their own variance. Higher output growth is followed by lower output variance in the following quarters (column 3, rows 1). In other words, uncertainty about future output growth is smaller in booms than in recessions. ${ }^{11}$ In contrast, the variance of banking sector stability increases when the banking sectors distance-to-default is high (column 4, rows 3 and 4). This signifies that uncertainty about future banking sector stability is higher during periods of stability. Combined with the positive autocorrelation for the banking sector described previously, our results imply that an unstable banking sector is more likely to be followed by a further period of instability, than a stable banking sector is to be followed by another period of stability.

Table 1 additionally shows that banking sector stability has a negative and significant impact on output growth variance (column 3, row 3). This means that a stable banking sector is followed by reduced uncertainty about future output growth. Combined with the positive link between banking sector stability and output growth, our findings indicate that a stable banking sector

\footnotetext{
${ }^{11}$ This is in line with the negative link between variance and growth identified by Ramey and Ramey (1995) and Fatás and Mihov (2003).
} 
Fig. 3. IMPULSE-RESPONSE FUNCTION FOR REAL OUTPUT GROWTH AND BANKING SECTOR STABILITY
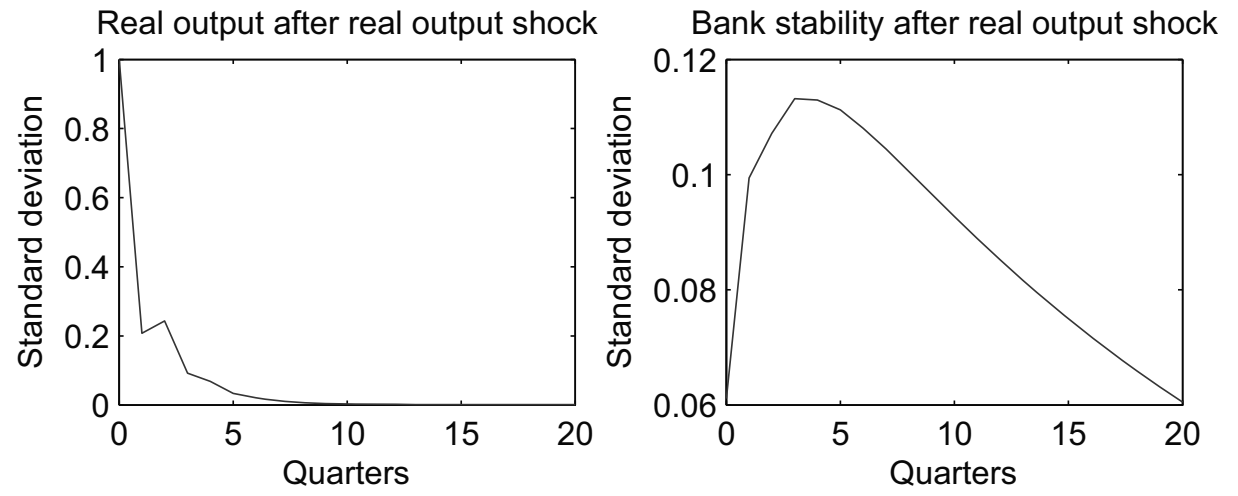

Real output after bank stability shock
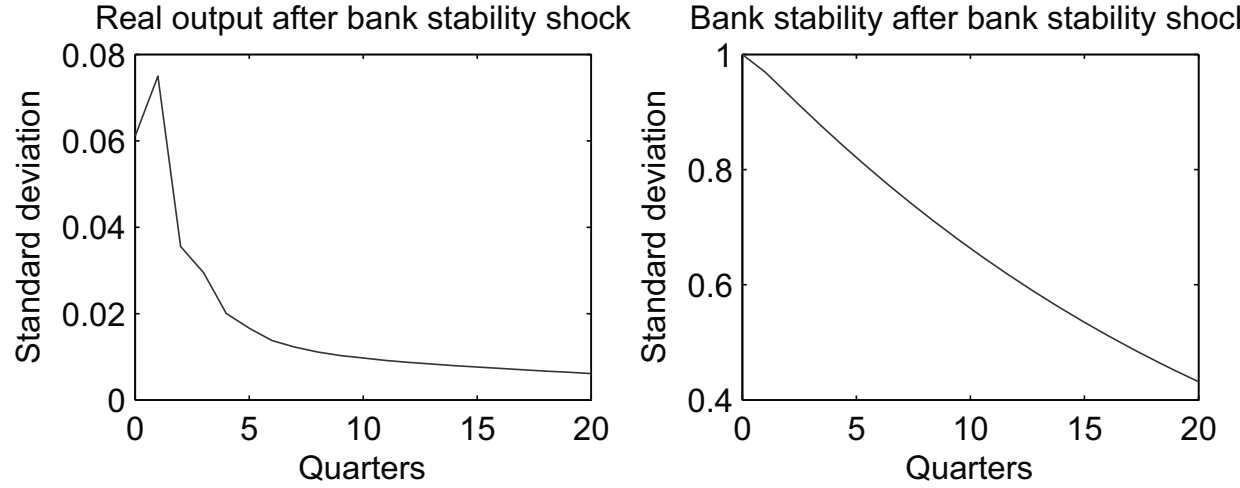

is more likely to be followed by high output growth, than an unstable banking sector is to be followed by low output growth. Interestingly, we find that higher uncertainty about the stability of the banking sector generally follows higher output growth (column 4, row 2). Combined with the positive link between output growth and banking sector stability, this means that, eventhough banking sectors are on average more stable after a growth in output, the probability of observing a banking crisis is higher after a period of growth.

Figure 4 documents the behavior of output growth and banking sector stability variances after shocks. The graph shows the difference between the average variance with and without shocks. As explained previously, a positive shock (to either output growth or to banking sector stability) reduces the variance of output growth (left-hand side panels). A positive shock to banking sector stability increases its own variance (right-hand side lower panel). Finally, a shock to output growth increases banking sector stability variance (right-hand side upper panel). 
Fig. 4. IMPULSE-RESPONSE FUNCTION FOR REAL OUTPUT GROWTH AND BANKING SECTOR STABILITY VARIANCE
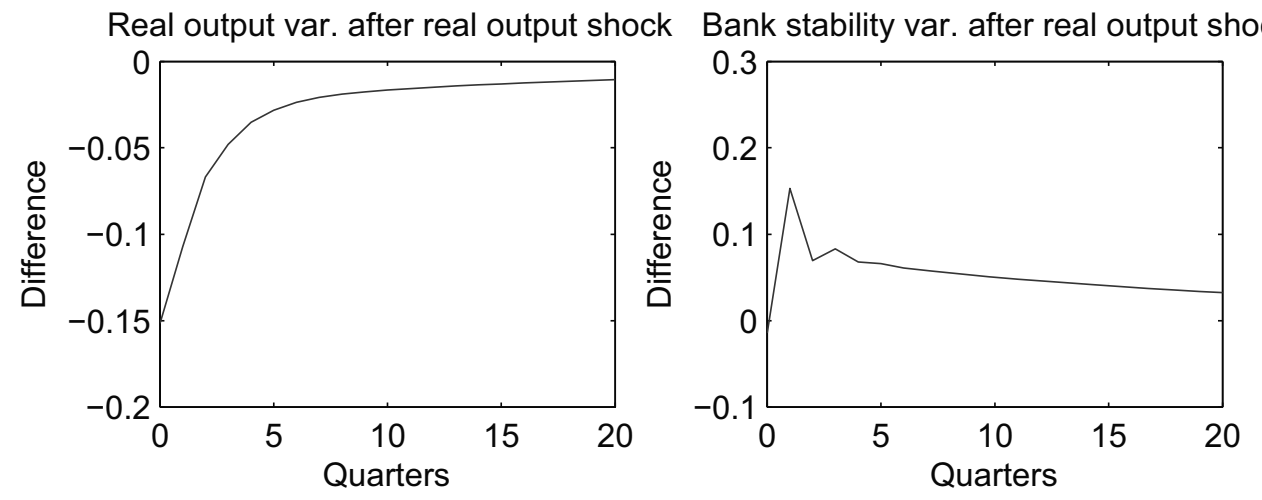

Real output var. after bank stability shockBank stability var. after bank stability shock
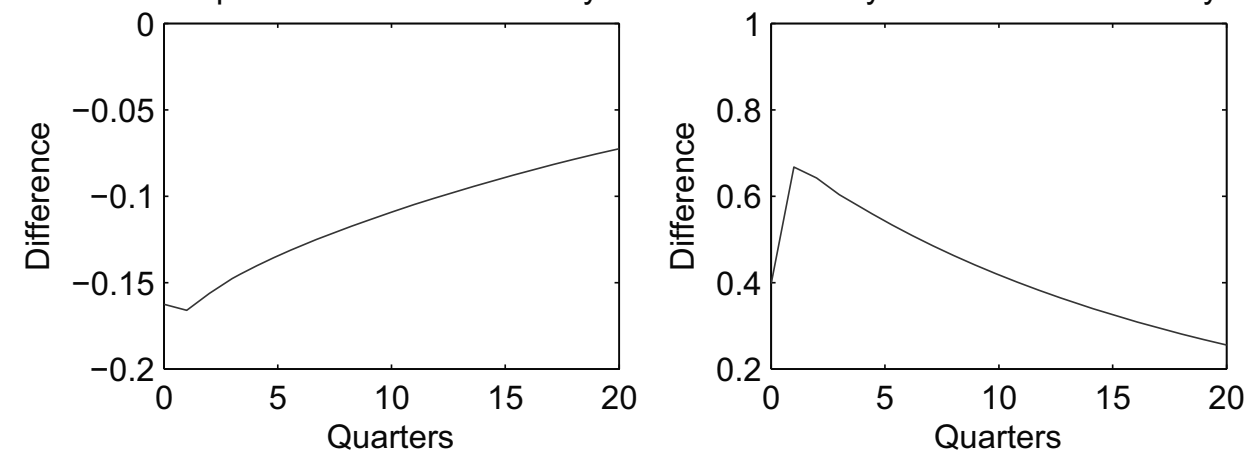

\subsubsection{Impact on inflation}

Table 2 presents the estimated pVAR with inflation and distance-to-default as endogenous variables with a lag of $2 .{ }^{12}$ It shows that neither inflation nor banking sector stability has an impact on the other. The results for the variance equations and for their impulse-response functions (Figure 5) show that higher inflation increases the uncertainty about next period inflation, but decreases the variance of distance-to-default after one period. Impulseresponse functions additionally show that the variance of inflation tends to decrease for a very short period after a positive shock to banking sectors degree of stability.

\subsection{Non linear impact of the banking sector stability}

In the previous section we showed that some empirical evidence of a linear link between banking sector stability and the distribution of output growth exists. However, some authors have suggested that the main impact of banking sector stability on the real economy is non linear. In this section, we briefly

\footnotetext{
${ }^{12}$ The number of lag is determined by the Akaike Information Criterion.
} 
TABLE 2

LINEAR IMPACT OF BANKING SECTOR STABILITY ON INFLATION

\begin{tabular}{c|cc|cc}
\hline \hline & \multicolumn{2}{|c|}{ Level } & \multicolumn{2}{c}{ Variance } \\
& Inflation $_{t}$ & $D D_{t}$ & $\log \left(\sigma_{I n f l_{t}}^{2}\right)$ & $\log \left(\sigma_{D D_{t}}^{2}\right)$ \\
\hline Inflation $_{t-1}$ & $1.0458^{* *}$ & 0.0007 & 0.0623 & $0.1427^{* *}$ \\
Inflation $_{t-2}$ & $-0.1237^{* *}$ & -0.0080 & $0.1143^{*}$ & $-0.1910^{* *}$ \\
DD $_{t-1}$ & -0.0487 & $0.9765^{* *}$ & $0.2286^{* *}$ & $0.5770^{* *}$ \\
$D_{t-2}$ & 0.0330 & -0.0254 & $-0.2172^{* *}$ & $0.3480^{* *}$ \\
Oil $_{t}$ & $0.5015^{* *}$ & -0.0428 & & \\
Oil $_{t-1}$ & $0.1309^{*}$ & -0.0097 & & \\
Oil $_{t-2}$ & $0.3227^{* *}$ & -0.0280 & & \\
\hline \hline
\end{tabular}

$\left.*^{* *}\right)$ indicates that the coefficient at significant at the $5 \%(1 \%)$ level. Level: estimated coefficients of equation (8) with inflation and banking sector's distance-to-default as endogenous variables and oil price ield as exogenous variable. Variance: estimated coefficients for vartion (12) with inflation and bagking sector's distaniante: estimated coefncients for equation (12) with inflation and banking sector's distance-to-default as independen

FIG. 5. IMPULSE-RESPONSE FUNCTION FOR INFLATION AND BANKING SECTOR STABILITY VARIANCE
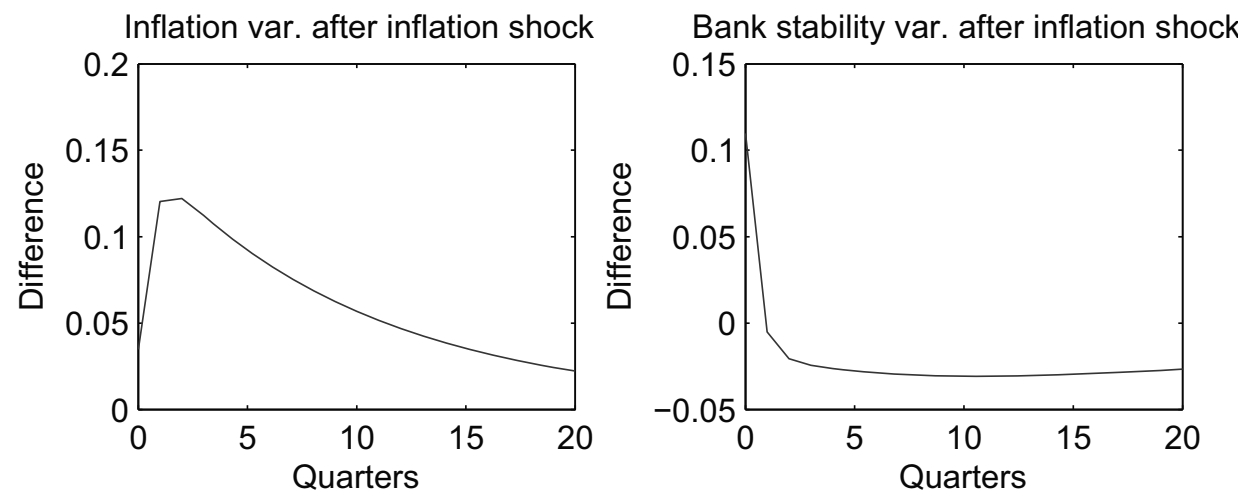

Inflation var. after bank stability shock
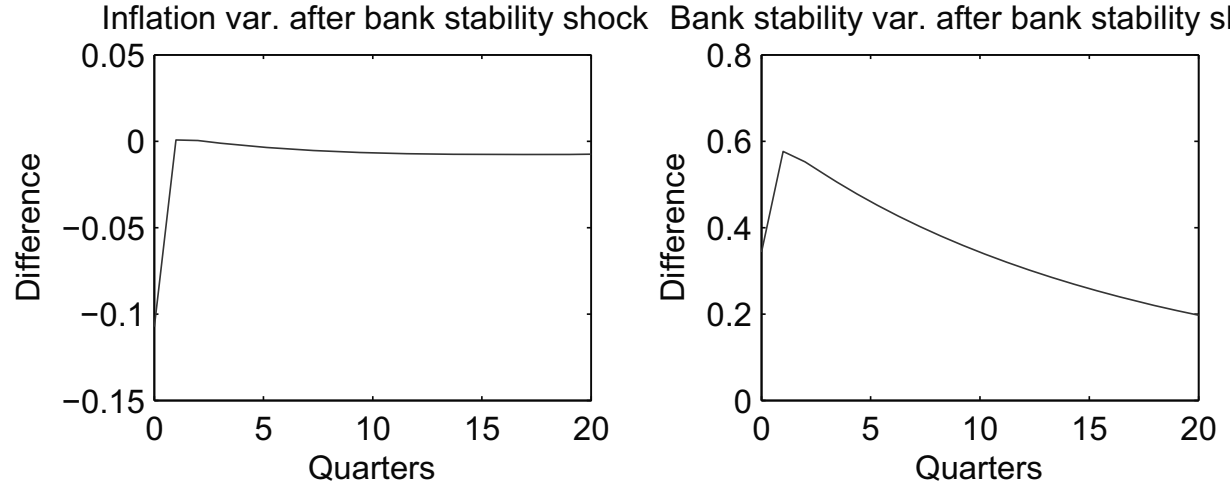

investigate this possibility with a simple model.

Concretely, we check whether there is an asymmetric reaction of real output growth and inflation to banking sector stability. Essentially, we assess whether real output and inflation distributions are different in periods following different state of banking sector stability. As per section 3, we define three states for 
TABLE 3

NON LINEAR IMPACT OF BANKING SECTOR STABILITY ON REAL OUTPUT GROWTH

\begin{tabular}{c|cc|cc}
\hline \hline & \multicolumn{2}{|c|}{ Level } & \multicolumn{2}{c}{ Variance } \\
& $G D P_{t}$ & $D D_{t}$ & $\log \left(\sigma_{G D P_{t}}^{2}\right)$ & $\log \left(\sigma_{D D_{t}}^{2}\right)$ \\
\hline$G D P_{t-1}$ & $0.1969^{* *}$ & $4.0539^{* *}$ & $-17.0826^{* *}$ & -2.2483 \\
$G D P_{t-2}$ & $0.2115^{* *}$ & $3.2440^{* *}$ & $-8.3040^{*}$ & 7.0877 \\
$D_{1, t-1}$ & $-0.0019^{* *}$ & $-0.6422^{* *}$ & 0.1445 & $-0.3709^{* *}$ \\
$D_{1, t-2}$ & $0.0016^{* *}$ & $-0.3758^{* *}$ & $0.3846^{* *}$ & $-1.2010^{* *}$ \\
$D_{2, t-1}$ & 0.0008 & $1.1228^{* *}$ & -0.2373 & $0.3551^{* *}$ \\
$D_{2, t-2}$ & -0.0004 & $0.4656^{* *}$ & $-0.3045^{*}$ & $0.1747^{* *}$ \\
Oil $_{t}$ & 0.0007 & -0.0209 & & \\
Oil $_{t-1}$ & $-0.0019^{* *}$ & 0.0067 & & \\
Oil $_{t-2}$ & -0.0012 & 0.0214 & & \\
\hline \hline
\end{tabular}

$\left.*^{* *}\right)$ indicates that the coefficient at significant at the $5 \%(1 \%)$ level. Level: estimated coefficients of equation (8) with inflation and banking sector's distance-to-default as endogenous variables and oil price yield as exogens variable. Variance: estimated coefficients for equation (12) with inflation and banking sector's distance-to-default as independent variables.

the banking sector: unstable, stable and very stable. We say that the banking sector is unstable if its (standardized) distance-to-default is in the first 20

Similarly to the linear estimations, we make use of a panel VAR but we replace the lagged distance-to-default of the right-hand side of equation (8) by two dummy variables: $D_{1, t}$, is equal to one when the banking sector is unstable and zero otherwise; and $D_{2, t}$, is equal to one when the banking sector is very stable and zero otherwise.

Table 3 presents the estimated coefficients of the new pVAR. The results for the dummy variables are particularly interesting. They indicate that only unstable banking sectors have a significant (and negative) impact on real output growth. Particularly stable banking sectors have no impact on real output growth. In contrary, both unstable and very stable banking sectors have a significant impact on real output growth variance.

Table 4 presents the estimated coefficients of the non linear pVAR with inflation. The results are less clear than for the output growth, but it seems that unstable banking sector increase slightly inflation (column 1, row 4).

The non linear model provides some interesting insights into the results from the linear model for output growth. They show that the linear links uncovered are predominantly driven by periods of banking sector instability rather than by a smooth and continuous link between banking sector stability and the real economy. 
TABLE 4

NON LINEAR IMPACT OF BANKING SECTOR STABILITY ON INFLATION

\begin{tabular}{l|cc|cc}
\hline \hline & \multicolumn{2}{|c|}{ Level } & \multicolumn{2}{c}{ Variance } \\
& Inflation $_{t}$ & $D D_{t}$ & $\log \left(\sigma_{\text {Infl }}^{2}\right)$ & $\log \left(\sigma_{D D_{t}}^{2}\right)$ \\
\hline Inflation $_{t-1}$ & $1.0497^{* *}$ & -0.0173 & 0.0654 & 0.0386 \\
Inflation $_{t-2}$ & $-0.1259^{* *}$ & 0.0043 & 0.1034 & -0.0815 \\
$D_{1, t-1}$ & -0.0757 & $-0.6516^{* *}$ & 0.2017 & $-0.3533^{* *}$ \\
$D_{1, t-2}$ & $0.0985^{*}$ & $-0.3387^{* *}$ & -0.0224 & $-1.0098^{* *}$ \\
$D_{2, t-1}$ & -0.0485 & $1.1281^{* *}$ & -0.0161 & $0.2686^{*}$ \\
$D_{2, t-2}$ & 0.0427 & $0.4536^{* *}$ & 0.0456 & 0.2236 \\
Oil $_{t}$ & $0.5162^{* *}$ & -0.0189 & & \\
Oil & $0.1336^{*}$ & 0.0421 & & \\
Oil $_{t-2}$ & $0.3342^{* *}$ & 0.0847 & & \\
\hline
\end{tabular}

\subsection{Expanding the set of macroeconomic variables}

The model estimated in Section 4.1 is very simplistic since it makes the hypothesis that real output is function of its lags, of banking sector stability and of oil prices only. In reality, several other economic variables have an impact on output growth. In this section, we extend the set of exogenous macroeconomic variables included in the pVAR to capture their influence on real output growth. More precisely, we add consumption growth rate $\left(\Delta C_{t}\right)$, short term interest rates $\left(S T I R_{t}\right)$, money growth $\operatorname{rate}\left(\Delta M 2_{t}\right)$ growth and investments $\left(\Delta K_{t}\right)$ in the sample. ${ }^{13}$ We chose to present these results in a separate section and not directly in the main section because the variables that we include are not available for all the countries studied or for the same period. Indeed, after adding these variables, the sample is reduced to 15 countries instead of $18^{14}$ and the number of observation shrinks from 1757 data points to 1052.

Table 5 shows that real output growth and distance-to-default are still function of their own lag. As previously, real output growth is also dependent on banking sector stability. However, and contrary to the results in Section 4.1, banking sector stability does not depend on real output growth anymore. It is still a function of the macroeconomic environment as banking sector stability decrease for higher short term interest rates and higher investments (column

\footnotetext{
${ }^{13}$ We chose variables that are likely to influence transitory business cycles of GDP (see e.g. Stock and Watson, 1999) and not long term growth rates (like e.g. human capital, political environment, etc...). The reasons for that is mainly that we are not interested in the long term structural influence of the banking sector on growth but more in the transitory impact of the fluctuation of its stability.

${ }^{14}$ Australia, Greece and Sweden are missing from the initial sample.
} 
TABLE 5

LINEAR IMPACT OF BANKING SECTOR STABILITY

ON REAL OUTPUT GROWTH : EXTENDED SAMPLE

\begin{tabular}{c|cc|cc}
\hline \hline & \multicolumn{2}{|c|}{ Level } & \multicolumn{2}{c}{ Variance } \\
& $G D P_{t}$ & $D D_{t}$ & $\log \left(\sigma_{G D P_{t}}^{2}\right)$ & $\log \left(\sigma_{D D_{t}}^{2}\right)$ \\
\hline$G D P_{t-1}$ & $0.2313^{* *}$ & 2.2489 & $-12.5079^{*}$ & $-14.8445^{* *}$ \\
$G D P_{t-2}$ & $0.2032^{* *}$ & -0.9067 & -9.5655 & 0.3829 \\
$D D_{t-1}$ & $0.0008^{* *}$ & $0.8984^{* *}$ & $-0.2344^{* *}$ & $0.6176^{* *}$ \\
$D D_{t-2}$ & $-0.0008^{*}$ & -0.0081 & -0.0304 & $0.3826^{* *}$ \\
$O i l_{t}$ & 0.0011 & $0.1029^{*}$ & & \\
$O i l_{t-1}$ & -0.0011 & -0.0155 & & \\
$O i l_{t-2}$ & -0.0007 & 0.0074 & & \\
$\Delta M 2_{t-1}$ & $0.0136^{*}$ & 0.3182 & & \\
$S T I R_{t-1}$ & $-0.0003^{* *}$ & $-0.0200^{* *}$ & & \\
$\Delta C_{t-1}$ & $0.0848^{*}$ & 0.9168 & & \\
$\Delta K_{t-1}$ & $-0.0000^{* *}$ & $-0.0000^{* *}$ & \\
\hline \hline
\end{tabular}

*(**) indicates that the coefficient at significant at the $5 \%(1 \%)$ level. Level: estimated coefficients of equation (8) with GDP growth and banking sector's distance-to-default as endogenous variables and oil price yield as exogenous variable. Variance: estimated coefficients for equation (12) with GDP growth and banking sector's distance-to-default as independent variables.

2 , rows 9 and 11). Table 5 also shows that real output growth variance is still a negative function of banking sector stability - i.e. uncertainty about real output growth increases with banking sector instability. The introduction of the new variables changes the results for distance-to-default variance: the uncertainty about banking sector stability decreases with higher real output growth.

\section{$5 \quad$ Banking sector stability and central bank forecast errors}

The link between banking stability and economic activity is of particular interest to policy makers which base their monetary policy decisions on economic forecasts. Our estimations above highlighted the importance of banking sector stability on output growth, however, they were unable to identify any significant relationship between stability and inflation. We therefore extend our analysis on banking sector stability and GDP growth by assessing whether additional information embedded in our stability index might help to improve output growth forecasts. We base our analysis on the United States since forecast data is publicly available on the Fed website back to $1965^{15}$, up to a five year delay. For comparability with our previous estimations our dataset that consists of quarterly data from 1980 to 2001.

Despite econometric models playing an important role in Fed projections for

\footnotetext{
${ }^{15}$ http://www.philadelphiafed.org/econ/forecast/greenbook-data/index.cfm.
} 
TABLE 6

Correlations: Distance to DEFAult With FORECAST ERRORS

\begin{tabular}{l|cllll}
\hline \hline & $\mathrm{DD}(\mathrm{C})$ & $\mathrm{DD}(\mathrm{L} 1)$ & $\mathrm{DD}(\mathrm{L} 2)$ & $\mathrm{DD}(\mathrm{L} 3)$ & $\mathrm{DD}(\mathrm{L} 4)$ \\
\hline current & $-0.43^{* *}$ & $-0.46^{* *}$ & $-0.37^{* *}$ & $-0.33^{* *}$ & $-0.34^{* *}$ \\
one & 0.09 & -0.11 & 0.02 & 0.06 & 0.06 \\
two & $0.30^{* *}$ & $0.34^{* *}$ & $0.34^{* *}$ & $0.31^{* *}$ & $0.32^{* *}$ \\
three & $0.18^{*}$ & 0.17 & 0.13 & 0.10 & 0.10 \\
four & 0.02 & 0.01 & -0.07 & -0.05 & -0.04 \\
five & -0.10 & -0.14 & -0.16 & -0.17 & -0.16 \\
six & 0.17 & -0.14 & 0.13 & 0.17 & 0.16 \\
seven & -0.02 & -0.04 & -0.02 & -0.03 & -0.03 \\
eight & -0.05 & -0.04 & -0.04 & -0.06 & -0.06 \\
\hline \hline
\end{tabular}

Note: $\left.*^{* *}\right)$ denotes significance at the $5 \%(1 \%)$ level. Forecast errors are calculated as the difference between actual and predicted GDP growth. On the vertical axis, current, one... refer to the current forecest, the one-period ahead forecast etc. $\mathrm{DD}(\mathrm{C}), \mathrm{DD}(\mathrm{L} 1), \mathrm{DD}(\mathrm{L} 2)$ denote the current stability, stability with a one period lag, stability with a two period lag.

macroeconomic growth, they serve only as part of an input into the forecast process. Judgement based intervention, incorporating additional information not grasped by the models, additionally play a vital role (see Reifschneider, Stockton, and Wilcox, 1997). It is, however, unclear what information is incorporated and whether such judgment based adjustments to forecasts are efficient, i.e. whether they for example make efficient use of all information contained in banking sector variables. Since economic activity and interest rates affect financial sector risks, and in turn, the financial sector affects the real economy, it is possible that considering the state of the banking sector in a systematic way would improve forecasts. We therefore investigate whether Fed growth forecasts are indeed making use of information contained in our measure of banking sector stability.

We start by computing simple correlations between the current distance to default and the period ahead forecasts. The correlations are presented in Table 6 . Correlations between the stability indicator and the forecast errors are significant for current forecasts as well as for two- and three-period ahead forecasts indicating that some degree of association between these two measures exists. Simple correlations, however, make no a priori assumptions as to whether one variable is dependent on the other. We therefore proceed to describe the dependence of forecast errors on the banking sector stability; implicitly assuming that there is a one-way causal effect from the degree of stability to the forecast errors, regardless of whether the path of effect is direct or indirect.

Our results are presented in Table 7 . We find that banking sector stability has a positive and significant impact on the two-and three-period ahead Fed forecasts. Since the forecast error is calculated as the difference between the actual value and the forecasted rate, the result indicates that banking sector 
TABLE 7

Estimation: DistANCE TO DEFAULT AND FED FORECAST ERRORS

\begin{tabular}{c|c|c|c|c}
\hline \hline $\begin{array}{c}\text { Dependent } \\
\text { variable: }\end{array}$ & $\begin{array}{c}\text { one-period } \\
\text { ahead forecast }\end{array}$ & $\begin{array}{c}\text { two-period } \\
\text { ahead forecast }\end{array}$ & $\begin{array}{c}\text { three-period } \\
\text { ahead forecast }\end{array}$ & $\begin{array}{c}\text { four-period } \\
\text { ahead forecast }\end{array}$ \\
\hline \hline
\end{tabular}

\begin{tabular}{|c|c|c|c|c|}
\hline distance to default & 0.04 & $0.08^{* *}$ & $0.022^{*}$ & 0.02 \\
\hline \multicolumn{5}{|c|}{ NON LINEAR ESTIMATIONS } \\
\hline$D_{1}$ & 0.28 & $0.61^{* *}$ & $0.38^{*}$ & 0.10 \\
\hline$D_{2}$ & -0.54 & -0.23 & -0.01 & -0.02 \\
\hline
\end{tabular}

stability today results in a significant underestimation of GDP growth the subsequent quarters. Essentially, banking sector stability brings more growth than expected. This finding indicates that additional information embedded in our stability index measure has the potential to improve Fed growth forecasts. We additionally experiment with asymmetric effects in this regard, defining periods of instability, stability and high stability as per section 3 . The results are presented in the lower panel of Table 7 . The results from the non linear estimation further confirm our previous finding that for the two-period (and three-period) ahead forecasts, instability drives the results.

\section{Conclusion}

In this paper, we explore the relationship between banking sector stability and the subsequent evolution of real output growth and inflation. Capturing the stability of a banking sector by building an index based on banking sector distance to default, we adopt a panel VAR methodology to assess both linear and non linear relationships between our variables of interest. We show that banking sector stability appears to be an important driver of GDP growth. Periods of stability are generally followed by an increase in real output growth, while instability corresponds with subsequent periods of reduced growth. We also show that a stable banking sector reduces real output growth uncertainty. In addition, we explore the possibility of an asymmetric impact of banking sector stability on the real economy. To do this we distinguish between unstable, stable and very stable periods relative to both historical and international average. We find that the relationship is asymmetric in nature, in that it is driven predominantly by periods of instability.

We further extend the analysis to assess whether additional information em- 
bedded in our stability index might help to improve central bank growth forecasts. Focussing on data from the Fed, we show that output forecast errors are correlated with our stability measure. Our findings indicate that banking sector stability (instability) results in a significant underestimation (overestimation) of GDP growth in the subsequent quarters. This result is in line with the notion that additional information, embedded in our stability index measure, has the potential to further improve economic forecasts.

Our findings have several important implications for policy makers. First, we show that for a sample of 18 countries, banking sector stability appears to be an important driver of GDP growth in subsequent periods, highlighting the need for greater attention to be paid to banking sector soundness in the implementation of economic policy. In addition, we find that additional information contained in our banking sector measure could help forecasters to reduce forecast errors, highlighting the need for policy makers to consider banking sector measures in their forecast models.

\section{References}

Allenspach, N., And J. Perrez (2008): "The interaction between the Swiss banking sector and the macroeconomy: results from a VAR-analysis," Swiss National Bank, mimeo.

Aspachs, O., C. A. Goodhart, D. P. Tsomocos, and L. Zicchino (2007): "Towards a measure of financial fragility," Annals of Finance, 3, $37-74$.

Benink, H., And G. Benston (2005): "The future of banking regulation in developed countries: lessons from and for europe," Financial Markets, Institutions and Instruments, 14, 289-328.

Bichsel, R., AND J. Blum (2004): "The relationship between risk and capital in Swiss commercial banks: a panel study," Applied Financial Economics, 14, 1-7.

Bollerslev, T. (1990): "Modeling the coherence in short-run nominal exchange rates: A multivariate generalized ARCH model," Review of Economics and Statistics, 72, 498-505.

Boyd, J. H., S. KwaK, And B. Smith (2005): "The real output losses associated with modern banking crises," Journal of Money, Credit and Banking, 37(4), 977-999.

Dell'Ariccia, G., E. Detragiache, and R. Rajan (2008): "The real effect of banking crises," Journal of Financial Intermediation, 17, 89-112.

DemirgüÇ-Kunt, A., And E. Detragiache (1997): "The determinants of banking crises in developing and developed countries," IMF Staff Papers, $45,81-109$. 
(2005): "Cross-country empirical studies of systemic bank distress : a survey," IMF Working Paper, 05/96.

DemirgüÇ-Kunt, A., And V. Maksimovic (1998): "Law, finance, and firm growth," Mathematical Finance, 53, 2107-2137.

Deutsche Bundesbank (2006): Financial Stability Review.

DuAn, J.-C. (1994): "Maximum likelihood estimation using price data of the derivative contract," Mathematical Finance, 4, 155-167.

(2000): "Correction: maximum likelihood estimation using price data of the derivative contract," Mathematical Finance, 10, 461-462.

European Central Bank (2006): "Country-level macro stress-testing practices," Financial Stability Report, pp. 147-154.

Fatás, A., And I. Minov (2003): "The Case for restricting fiscal policy discretion," Quarterly Journal of Economics, 118, 1419-1447.

Goodhart, C. A., P. Sunirand, and D. P. Tsomocos (2006): "A model to analyse financial fragility," Economic Theory, 27.

Gupta, P. (2005): "Aftermath of banking crises: Effects on real and monetary variables," Journal of International Money and Finance, 24, 675-691.

HARvey, A. C. (1976): "Estimating regression models with multiplicative heteroscedasticity," Econometrica, 44(3), 461-465.

Hilbers, P., I. Otker-Robe, C. Pazarbasioglu, and G. Johnsen (2005): "Assessing and managing rapid credit growth and the role of supervisory and prudential policies," IMF Working Paper, 05/151.

Hogart, G., R. Reis, and V. Saporta (2002): "Costs of banking system instability: some empirical evidence," Journal of Banking and Finance, 26, 825-855.

Kaminsky, G., and C. Reinhart (1999): "The twin crises: the causes of banking and balance of payments problems," American Economic Review, 89, 473-500.

King, R. G., And R. Levine (1993a): "Finance and growth: Schumpeter might be right," Journal of Financial Economics, 108, 717-738.

- (1993b): "Finance, entrepreneurship, and growth: theory and evidence," Journal of Monetary Economics, 32, 513-542.

Kroszner, R. S., L. Laeven, and D. Klingebiel (2007): "Banking crises, financial dependence, and growth," Journal of Financial Economics, 84, $187-225$.

Levine, R. (1997): "Financial development and economic growth: views and agenda," Journal of Economic Literature, 35, 688-726.

- (1998): "The legal environment, banks, and long -run economic growth," Journal of Money, Credit, and Banking, 30, 596-620.

- (2001): "International financial liberalization and economic growth," Review of International Economics, 9, 688-702.

- (2004): "Finance and growth: theory, evidence, and mechanisms," in Handbook of Economic Growth, ed. by P. Aghion, and S. Durlauf. Elsevier.

Levine, R., N. LoAyza, And T. Beck (2000): "Financial intermediation and growth: causality and causes," Journal of Monetary Economics, 35, 
$31-77$.

Merton, R. (1974): "On the pricing of corporate debt: the risk structure of interest rates," Journal of Finance, 29, 449-470.

Peek, J., E. S. Rosengren, and G. M. B. Tootell (1999): "Is bank supervision central to central banking?," Quarterly Journal of Economics, 114, 629-655.

(2003): "Does the Federal Reserve possess an exploitable informational advantage?," Journal of Monetary Economics, 50, 817-839.

Rajan, R. G., And L. Zingales (1986): "Financial dependence and growth," American Economic Review, 88, 559-586.

Ramey, G., and V. A. Ramey (1995): "Cross-country evidence on the link between volatility and growth," American Economic Review, 85, 1138-1151.

Rancière, R., A. Tornell, and F. Westermann (2008): "Systemic crises and growth," Quarterly Journal of Economics, 123, 359-406.

Reifschneider, D. L., D. J. Stockton, and D. W. Wilcox (1997): "Econometric models and the monetary policy process," Carnegie-Rochester Conference Series on Public Policy, 47, 1-37.

Romer, C. D., And D. H. Romer (2000): "Pricing risk-adjusted deposit insurance: an option based model," American Economic Review, 90, 429457.

SERWA, D. (2007): "Larger crises cost more: impact of banking sector instability on output growth," MPRA Paper, 5101.

Stock, J. H., And M. W. Watson (1999): "Business cycle fluctuations in U.S. macroeconomic time series," in Handbook of Macroeconomics, ed. by J. Taylor, and M. Woodford. Elsevier. 


\section{Swiss National Bank Working Papers published since 2004:}

2004-1 Samuel Reynard: Financial Market Participation and the Apparent Instability of Money Demand

2004-2 Urs W. Birchler and Diana Hancock: What Does the Yield on Subordinated Bank Debt Measure?

2005-1 Hasan Bakhshi, Hashmat Khan and Barbara Rudolf: The Phillips curve under state-dependent pricing

2005-2 Andreas M. Fischer: On the Inadequacy of Newswire Reports for Empirical Research on Foreign Exchange Interventions

2006-1 Andreas M. Fischer: Measuring Income Elasticity for Swiss Money Demand: What do the Cantons say about Financial Innovation?

2006-2 Charlotte Christiansen and Angelo Ranaldo: Realized Bond-Stock Correlation: Macroeconomic Announcement Effects

2006-3 Martin Brown and Christian Zehnder: Credit Reporting, Relationship Banking, and Loan Repayment

2006-4 Hansjörg Lehmann and Michael Manz: The Exposure of Swiss Banks to Macroeconomic Shocks - an Empirical Investigation

2006-5 Katrin Assenmacher-Wesche and Stefan Gerlach: Money Growth, Output Gaps and Inflation at Low and High Frequency: Spectral Estimates for Switzerland

2006-6 Marlene Amstad and Andreas M. Fischer: Time-Varying Pass-Through from Import Prices to Consumer Prices: Evidence from an Event Study with Real-Time Data

2006-7 Samuel Reynard: Money and the Great Disinflation

2006-8 Urs W. Birchler and Matteo Facchinetti: Can bank supervisors rely on market data? A critical assessment from a Swiss perspective

2006-9 Petra Gerlach-Kristen: A Two-Pillar Phillips Curve for Switzerland

2006-10 Kevin J. Fox and Mathias Zurlinden: On Understanding Sources of Growth and Output Gaps for Switzerland

2006-11 Angelo Ranaldo: Intraday Market Dynamics Around Public Information Arrivals

2007-1 Andreas M. Fischer, Gulzina Isakova and Ulan Termechikov: Do FX traders in Bishkek have similar perceptions to their London colleagues? Survey evidence of market practitioners' views 
2007-2 Ibrahim Chowdhury and Andreas Schabert: Federal Reserve Policy viewed through a Money Supply Lens

2007-3 Angelo Ranaldo: Segmentation and Time-of-Day Patterns in Foreign Exchange Markets

2007-4 Jürg M. Blum: Why ‘Basel II' May Need a Leverage Ratio Restriction

2007-5 Samuel Reynard: Maintaining Low Inflation: Money, Interest Rates, and Policy Stance

2007-6 Rina Rosenblatt-Wisch: Loss Aversion in Aggregate Macroeconomic Time Series

2007-7 Martin Brown, Maria Rueda Maurer, Tamara Pak and Nurlanbek Tynaev: Banking Sector Reform and Interest Rates in Transition Economies: Bank-Level Evidence from Kyrgyzstan

2007-8 Hans-Jürg Büttler: An Orthogonal Polynomial Approach to Estimate the Term Structure of Interest Rates

2007-9 Raphael Auer: The Colonial Origins Of Comparative Development: Comment. A Solution to the Settler Mortality Debate

2007-10 Franziska Bignasca and Enzo Rossi: Applying the Hirose-Kamada filter to Swiss data: Output gap and exchange rate pass-through estimates

2007-11 Angelo Ranaldo and Enzo Rossi: The reaction of asset markets to Swiss National Bank communication

2007-12 Lukas Burkhard and Andreas M. Fischer: Communicating Policy Options at the Zero Bound

2007-13 Katrin Assenmacher-Wesche, Stefan Gerlach, and Toshitaka Sekine: Monetary Factors and Inflation in Japan

2007-14 Jean-Marc Natal and Nicolas Stoffels: Globalization, markups and the natural rate of interest

2007-15 Martin Brown, Tullio Jappelli and Marco Pagano: Information Sharing and Credit: Firm-Level Evidence from Transition Countries

2007-16 Andreas M. Fischer, Matthias Lutz and Manuel Wälti: Who Prices Locally? Survey Evidence of Swiss Exporters

2007-17 Angelo Ranaldo and Paul Söderlind: Safe Haven Currencies 
2008-1 Martin Brown and Christian Zehnder: The Emergence of Information Sharing in Credit Markets

2008-2 Yvan Lengwiler and Carlos Lenz: Intelligible Factors for the Yield Curve

2008-3 Katrin Assenmacher-Wesche and M. Hashem Pesaran: Forecasting the Swiss Economy Using VECX* Models: An Exercise in Forecast Combination Across Models and Observation Windows

2008-4 Maria Clara Rueda Maurer: Foreign bank entry, institutional development and credit access: firm-level evidence from 22 transition countries

2008-5 Marlene Amstad and Andreas M. Fischer: Are Weekly Inflation Forecasts Informative?

2008-6 Raphael Auer and Thomas Chaney: Cost Pass Through in a Competitive Model of Pricing-to-Market

2008-7 Martin Brown, Armin Falk and Ernst Fehr: Competition and Relational Contracts: The Role of Unemployment as a Disciplinary Device

2008-8 Raphael Auer: The Colonial and Geographic Origins of Comparative Development

2008-9 Andreas M. Fischer and Angelo Ranaldo: Does FOMC News Increase Global FX Trading?

2008-10 Charlotte Christiansen and Angelo Ranaldo: Extreme Coexceedances in New EU Member States' Stock Markets

2008-11 Barbara Rudolf and Mathias Zurlinden: Measuring capital stocks and capital services in Switzerland

2008-12 Philip Sauré: How to Use Industrial Policy to Sustain Trade Agreements

2008-13 Thomas Bolli and Mathias Zurlinden: Measuring growth of labour quality and the quality-adjusted unemployment rate in Switzerland

2008-14 Samuel Reynard: What Drives the Swiss Franc?

2008-15 Daniel Kaufmann: Price-Setting Behaviour in Switzerland - Evidence from CPI Micro Data

2008-16 Katrin Assenmacher-Wesche and Stefan Gerlach: Financial Structure and the Impact of Monetary Policy on Asset Prices

2008-17 Ernst Fehr, Martin Brown and Christian Zehnder: On Reputation: A Microfoundation of Contract Enforcement and Price Rigidity 
2008-18 Raphael Auer and Andreas M. Fischer: The Effect of Low-Wage Import Competition on U.S. Inflationary Pressure

2008-19 Christian Beer, Steven Ongena and Marcel Peter: Borrowing in Foreign Currency: Austrian Households as Carry Traders

2009-1 Thomas Bolli and Mathias Zurlinden: Measurement of labor quality growth caused by unobservable characteristics

2009-2 Martin Brown, Steven Ongena and Pinar Yeșin: Foreign Currency Borrowing by Small Firms

2009-3 Matteo Bonato, Massimiliano Caporin and Angelo Ranaldo: Forecasting realized (co)variances with a block structure Wishart autoregressive model

2009-4 Paul Söderlind: Inflation Risk Premia and Survey Evidence on Macroeconomic Uncertainty

2009-5 Christian Hott: Explaining House Price Fluctuations

2009-6 Sarah M. Lein and Eva Köberl: Capacity Utilisation, Constraints and Price Adjustments under the Microscope

2009-7 Philipp Haene and Andy Sturm: Optimal Central Counterparty Risk Management

2009-8 Christian Hott: Banks and Real Estate Prices

2009-9 Terhi Jokipii and Alistair Milne: Bank Capital Buffer and Risk Adjustment Decisions

2009-10 Philip Sauré: Bounded Love of Variety and Patterns of Trade

2009-11 Nicole Allenspach: Banking and Transparency: Is More Information Always Better?

2009-12 Philip Sauré and Hosny Zoabi: Effects of Trade on Female Labor Force Participation

2009-13 Barbara Rudolf and Mathias Zurlinden: Productivity and economic growth in Switzerland 1991-2005

2009-14 Sébastien Kraenzlin and Martin Schlegel: Bidding Behavior in the SNB's Repo Auctions

2009-15 Martin Schlegel and Sébastien Kraenzlin: Demand for Reserves and the Central Bank's Management of Interest Rates

2009-16 Carlos Lenz and Marcel Savioz: Monetary determinants of the Swiss franc 
2010-1 Charlotte Christiansen, Angelo Ranaldo and Paul Söderlind: The Time-Varying Systematic Risk of Carry Trade Strategies

2010-2 Daniel Kaufmann: The Timing of Price Changes and the Role of Heterogeneity

2010-3 Loriano Mancini, Angelo Ranaldo and Jan Wrampelmeyer: Liquidity in the Foreign Exchange Market: Measurement, Commonality, and Risk Premiums

2010-4 Samuel Reynard and Andreas Schabert: Modeling Monetary Policy

2010-5 Pierre Monnin and Terhi Jokipii: The Impact of Banking Sector Stability on the Real Economy 
Swiss National Bank Working Papers are also available at www.snb.ch, section Publications/Research Subscriptions or individual issues can be ordered at Swiss National Bank, Fraumünsterstrasse 8, CH-8022 Zurich, fax+41 4463181 14, E-mail library@snb.ch 